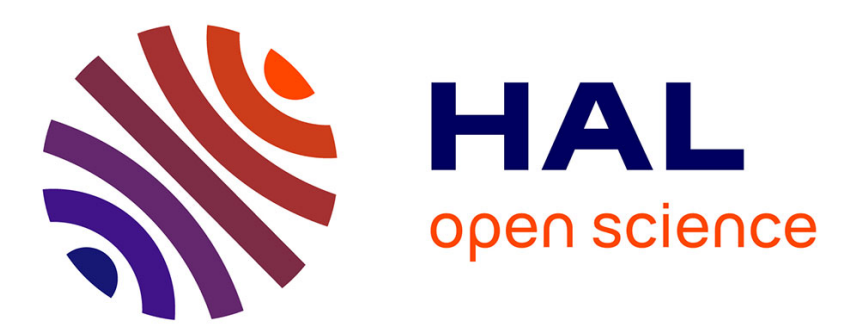

\title{
Reproductive biology of Paracentrotus lividus (Echinodermata: Echinoidea) in two contrasting habitats of northernTunisia (south-east Mediterranean)
}

Fériel Sellem, Monique Guillou

\section{- To cite this version:}

Fériel Sellem, Monique Guillou. Reproductive biology of Paracentrotus lividus (Echinodermata: Echinoidea) in two contrasting habitats of northernTunisia (south-east Mediterranean). non, 2007, France. pp.736-767, 10.1017/S002531540705521X . hal-00461268

\section{HAL Id: hal-00461268 \\ https://hal.univ-brest.fr/hal-00461268}

Submitted on 4 Mar 2010

HAL is a multi-disciplinary open access archive for the deposit and dissemination of scientific research documents, whether they are published or not. The documents may come from teaching and research institutions in France or abroad, or from public or private research centers.
L'archive ouverte pluridisciplinaire HAL, est destinée au dépôt et à la diffusion de documents scientifiques de niveau recherche, publiés ou non, émanant des établissements d'enseignement et de recherche français ou étrangers, des laboratoires publics ou privés. 
Reproductive biology of Paracentrotus lividus (Echinodermata, Echinoidea) in two contrasting habitats of northern Tunisia (southeast Mediterranean)

Running head : P. lividus reproduction in Northern Tunisia

Fériel Sellem ${ }^{1}$ and Monique Guillou ${ }^{2}$

${ }^{1}$ Institut National des Sciences et Technologies de la Mer - 28, rue du 2 mars 1934 - 2025 Salammbô, Tunisie.

${ }^{2}$ LEMAR, UMR CNRS 6539, Institut Universitaire Européen de la Mer. UBO, 29280 Plouzané, France.

${ }^{2}$ Corresponding author, e-mail :m.guillou@univ-brest.fr

\section{Abstract}

The reproductive strategies of the sea urchin, Paracentrotus lividus, was studied in the Bay of Tunis. Samples were collected monthly, from September 1993 to August 1995, in two sites which differ in their marine vegetation and their exposure to wave action. Histological examination demonstrated a cycle of gametogenesis with six reproductive stages and a main breeding period occurring between April and June. Gonad indices varied between sites and years, the sheltered site presenting a higher investment in reproduction. This difference was essentially induced by the largest sea urchins (above $40 \mathrm{~mm}$ in diameter). Repletion indices showed a clear pattern without difference between sites and years. The sea urchin increase in feeding activity was controlled by the need to allocate nutrient to the gonad during the mature stage. But the gonad investment was not correlated with the intensity of food intake. Hydrodynamic conditions might play a key role in diverting energy to the maintenance in an exposed environment at the expense of reproduction.

Key words : South Mediterranean - Paracentrotus lividus - Reproduction - feeding indexhydrodynamics. 


\section{INTRODUCTION}

The edible Atlanto-Mediterranean Sea urchin Paracentrotus lividus (Lamarck, 1816) is the most common echinoid species in sublittoral habitats in the Mediterranean Sea (Lozano et al., 1995; Boudouresque \& Verlaque, 2001). It is a species of an ecological and commercial importance. The grazing activity of this herbivore is known to affect the macrophytic structure and biomass (Verlaque \& Nédélec, 1983; Fanelli et al., 1994). Moreover its gonads are very appreciated in Mediterranean countries and the human predation has drastically depleted the populations in some areas.During the last decade, the production of this species has declined and the total production reached $48 \mathrm{t}$ in 1997 while it was $400 \mathrm{t}$ in 1992 (Keesing \& Hall, 1998). In the Atlantic coasts the species has been overfished to such a point that in Brittany the fisheries were halted at the end of the 1970s (Southward \& Southward, 1975) and in Ireland, they declined from the mid-1980s (Moylan et al., 1998). In Mediterranean Sea the situation is variable; intense overfishing has caused depletions on the French coasts (Gras, 1987) while in other regions the species was little or not exploited such as in Greece or North Africa (Le Direac'h et al., 1987; Guettaf et al., 2000). These fisheries could be an interesting commercial opportunity in front of the increasing demand. However gonad yield highly varies with environmental conditions (Byrne, 1990; Gago et al., 2001; Sanchez-Espana et al., 2004; Bayed et al., 2005). A good understanding of the status of these sea urchin fisheries is necessary to sustain harvest, especially data on the population dynamics and knowledge on the reproductive cycle and adaptation to change in environmental conditions. If many studies have analyzed Paracentrotus lividus reproduction in the north Mediterranean Sea and in the Atlantic (Fenaux, 1968, Crapp \& Willis, 1975 ; Byrne, 1990, Lozano et al., 1995, Fernandez \& Boudouresque, 1997; Sanchez-Espana et al., 2004), data are lacking in the southern Mediterranean where the species is locally abundant (Semroud \& Kada, 1987 ; Guettaf et al., 2000, Sellem et al, 2001). 
The aim of this paper was to determine the annual cycle of gonadal growth of $P$. lividus in an area potentially exploitable, easily accessible and where the production can be sold fast, the Bay of Tunis (in northern Tunisia). The reproductive strategy of the species was investigated through an analysis of the gonad index and histological examinations. As the gonad condition can vary with environmental factors such as temperature, hydrodynamics or trophic conditions, two contrasting habitats were chosen in this area. Two years were studied to observe possible interannual changes in the gonadal growth. The relationships between the gonad and the repletion indices was analysed in the different conditions. The results were compared with variable reproductive parameters (go nad size, number of spawning periods) in other P. lividus and other sea urchin populations from different ecological situations.

\section{MATERIALS AND METHODS}

Investigations were carried out in the south east part of the bay of Tunis $\left(36^{\circ} 46 \mathrm{~N}\right.$; $\left.10^{\circ} 30 \mathrm{E}\right)$ in two not-to-distant sites presenting contrasted environmental conditions from September 1993 to August 1995. The first one is a small and sheltered fishing port characterized by a sandy bottom with a meadow of Posidonia oceanica (Lineaus) Delile. This site was named 'meadow'. Sea urchins were localized in shallow depressions (about $3 \mathrm{~m}$ deep). In contrast, in the second site, sea urchins inhabited an exposed rocky shore covered with photophilic algae. This site was named 'rock'. Main macroalgae are the green algae (Chlorophyta), Ulva lactuca (Lineaus), Enteromorpha compressa (Lineaus) and Cladophora prolifera (Roth), the brown algae (Fucophyceae), Cystoseira mediterranea (Turner), Dictyota dichotoma (Hudson) and Padina pavonica (Lineaus) and the red algae (Rhodophyta), Corallina officinalis (Lineaus) and Jania rubens (Lineaus). In both sites, the water temperature ranged from 13 to $23.8^{\circ} \mathrm{C}$ and the salinity from 36.5 to 37.4 (Ben Charrada, 1997). 
In both site, approximately 70 individuals were collected monthly in shallow waters (1-3m) during two years from September 1993 to August 1995. Test diameter without the spines was measured in $\mathrm{mm}$ at the ambitus. For each site 10 urchins of $35-70 \mathrm{~mm}$ diameter were selected for gonad histology from September 1993 to August 1994. Gonads removed from the freshly dissected urchins were preserved in Bouin's fluid (Martoja \& Martoja, 1967). A central portion of the gonads was dehydrated in alcohol, embedded in paraffin wax and divided into sections of $7 \mu \mathrm{m}$, which were stained with hematoxylin and eosin.

The other 60 individuals were dissected and the 5 gonads, the gut content and the eviscerated test (with Aristote lanterne) were separated. Sexes were determined according to the colour of the gonads and, if necessary, by smear observations. Gonads, gut content and tests were dried for 48 hours at $70^{\circ} \mathrm{C}$ and then weighted. All the individuals with gonad weight $<0.4 \mathrm{~g} \mathrm{DW}$ were considered to be immature or undifferentiated.

The gonad index (GI) and the repletion index (RI) were calculated as the ratio of gonads (or gut contents) dry weight $(\mathrm{g}) /$ eviscerated test dry weight of urchin $(\mathrm{g}) \times 100$. All these indices were monthly calculated for each site, for the two sexes and by size class of $5 \mathrm{~mm}$.

Differences between males and females were tested using a t-test $(P<0.05)$ after the homogeneity of the variances had been tested. To compare GI and RI indices, a 2-way ANOVA with time and site as factors and the post-hoc LSD multiple mean comparison test were used with the software STATISTICA 7.1. A t-test can be also used to compare GI or RI in pairs.

\section{RESULTS}

\section{Gonad histology}

The histological results were qualitatively similar to those of Byrne (1990) who distinguished six stages. The trends of oogenesis and spermatogenesis were quasi similar. From October to 
November early oocytes and spermatocytes increased and started forming clusters (growing stage). From December to January ovaries and testes presented an important gametogenesis development (premature stage). From February mature testes were packed with spermatozoa and the first males started spawning. Spawning was firstly observed in March for females. In April all the observed acini were full with mature ova and sperm (mature stage). In May ovaries and testes were almost spawned (partly spawned stage). But mature gametes were encountered until July (spent stage). From July to September nutritive phagocytes occupied most of the space available in the acini (recovery stage) and remained present until October and November to resorbe the non evacuated mature gametes.

\section{Changes in gonad index}

As no difference was detected between males and females using t test $(P<0.05)$, all the GI data were grouped. Only the size-class $45-55 \mathrm{~mm}$ was used in this analysis to minimize the bias due to variation of gonad index with body size.

In the 'meadow', the sea urchin GI presented an annual well defined cycle with a rapid increase between March and April $\left(P<10^{-5}\right)$ each year followed by one or two decreases which can extend to the autumn (Figure 1A). In the 'rock', the periodicity was less obvious and the GI changes were less distinct (Figure 1B). In both sites, the period of spawning onset was verified by the highest percent of stage 4 (mature stage) and 5 (partly spawned stage) in May and June.

The GI were compared during the period including maturity, spawning and spent stages, from April to July. They were statistically different among site but not among year (2 factor ANOVA, $P=0.022,0.188$, and 0.727 for factors 'site', 'year' and interaction between factors respectively). 
Comparison of GI between both sites indicated a higher gonad relative weight in 'meadow' than in 'rock', with a GI very significantly higher in April $\left(P<10^{-5}\right)$ just before the decrease.

\section{Changes in repletion index}

RI showed an annual and clear cycle with a period of high values between November and May or July according to the year and a summer period of low values. The period of high feeding intensity was interrupted by several decreases generally concomitant in both sites. The first peak occurred in December then the main peaks in February and April. A peak of lower intensity was observed in July (Figure 1 A and B).

Comparison of RI during the period of high values from November to June indicated no significant differences among site and year (2 factor ANOVA, $P=0.983,0.058$, and 2.18 for factors 'site', 'year' and interaction between factors respectively). A comparison of both sites respectively indicated a persistence of high values in both sites in May (t-t test, $P<0.05)$ and June $\left(P<10^{-5}\right)$ in 1995 compared to 1994.

\section{Relationship between physiological indices and size}

To establish these relationships all data were pooled by year i) from September 1993 to August 1994, ii) from September 1994 to August 1995. During the first year, in both sites GI presented a sharp increase for the sea urchins between 25 and $40 \mathrm{~mm}$ in diameter then the relationship between GI and size differed significantly between 'meadow' and 'rock' (t-test, $P$ $<0.01$ from the size-class 40-45) (Figure 2A). This difference was highly significant from the size-class 45-50 $\left(P<10^{-5}\right)$. In the 'rock', the GI course decreased from the size-class 40-45 while in the 'meadow' GI continued to increase from 50 to $65 \mathrm{~mm}$. However this highly significant different pattern between both localities did not happen again the next year. During 
this second period, the GI values coincided in both sites until $50 \mathrm{~mm}$; the GI trend was very close to the GI pattern on the 'rock' during the previous year.

During the two years, the RI did not vary with size between the size-classes 25-30 and 40-45 mm (Fig. 2). It decreased significantly (t-test, $P<0.05)$ in 'meadow' at the size class 50-55 mm during the two years and from the size-class 45-50 $\left(P<10^{-5}\right)$ in the 'rock' during the first year (Figure 2B). Except for this size-class 50-55 mm, no difference was observed between the two sites during the two years.

\section{DISCUSSION}

The comparison of the reproductive cycle of Paracentrotus lividus using changes in gonadal indices (GI) indicated a priori a very different pattern between the two studied sites. Such variation also has previously been documented in P. lividus but also in other echinoids. Their reproductive potential can vary spatially over short distances (King et al., 1994; Beddingfield \& McClintock, 1998; Meidel \& Scheibling, 1998; Guillou \& Lumingas, 1999; Brewin et al., 2000; Sanchez-Espana et al., 2004). In most cases, the variations were attributed to the variations in the quality of available food (Lawrence \& Lane, 1982) but also, in temperature and/or photoperiod (Gonor, 1973).

In this study, in the sheltered site 'meadow' the temporal trend was clear with one or two obvious peaks during spring. In the more exposed site 'rock', the GI trend was very irregular without emergence of a clear peak whatever the year. The GI values were very low compared to the literature (Byrne, 1990; Spirlet et al., 1998; Guettaf et al., 2000; Bayed et al., 2005; Fernandez, personal communication). The reproductive cycle of this species cannot be assessed using this only index. Gonad histology is necessary to interpret the observations. In both sites, the onset of the main spawning was indicated by a high percent of stages 5 (partly spawned stage) in April, May and June. The theory that $P$. lividus has two spawning periods 
per year in Mediterranean Sea was supported by many studies (Fenaux, 1968; Régis, 1979; Semroud \& Kada, 1987, Fenaux \& Pedrotti, 1988, C. Fernandez, personal communication) but criticized by Lozano et al. (1995). Our study confirms this last assertion and most part of the GI drops reported in this study was more changes in gonad reserves than gamete releases. But analysis of gonadal indices allows to compare the part allocated by the sea urchin to the reproductive compartment (gametogenesis and nutritive storage) between the two environment. A higher investment in reproduction was observed in the sheltered site. Analysis of the relationship between GI and size showed that this difference was essentially caused by the largest sea urchins (above $40 \mathrm{~mm}$ in diameter).

Relationships between gonadal and feeding indices of sea urchins were contrasted in the literature. In the present study the RI annual pattern was clear, quasi identical in both sites and from one year to the other. A period of high values and thus of intense feeding activity occurred from November to the end of spring. This period was interrupted by several decreases generally concomitant in both sites. The first drop, between December and January or February, could be induced by the coldest annual temperatures (Guillou \& Michel, 1994). The main peaks in February and April corresponded to the period of maximal gonad indices. This increase in feeding activity was thus targeted by the sea urchin need to allocate nutrient to the gonads. But if the reproductive trend can partially explain the trend of feeding indices in both sites, the gonad investment does not express the feeding intensity. The gonad investment was higher in 'meadow' than in 'rock' while feeding intensity was quasi-identical in both sites. In spring 1995, RI was even higher in 'rock' than in 'meadow'. These observations suggest that other factors that the quantity of ingested food control the intensity of the reproductive cycle. The effects of food quality which determine the quantity of absorbed nutrient can be considered. But in the present study, the macro algae present in the 'rock' site cannot have a caloric content lower than the Posidonia ingested by the sea urchins 
in the 'meadow' site. Régis (1980) observed a lower gonad yield in Posidonia bed than in rocks occupied by macro algae. As the two sites are not-too-distant, differences in temperature or photoperiod cannot be considered in the present study. But the different degree of wave exposure between the two environments may be the explanatory factor. Little is known about the effects of hydrodynamic conditions on the reproductive potential of sea urchins and the few results are contrasted. Lozano et al. (1995) in P. lividus and Meidel \& Scheibling in Strongylocentrotus droebachiensis pointed out that a higher hydrodynamism could lead to a higher investment in reproduction. In contrast, Ebert (1968) and Gonor (1973) indicated that Strongylocentrotus purpuratus had lower gonad indices at exposed sites than at sheltered sites. In the present study and in the Ebert's observations, the reproductive potential was lower in the wave-exposed site despite of a higher food abundance. Hydrodynamism level in 'rock' compared to 'meadow' thus appears as a limiting factor. Above a certain level, energy must be allocated to the maintenance, repair and test production (Himmelman, 1986) in front of wave exposure. Ebert (1968) attributed this difference in particular to a higher cost of spine repair at the exposed spine. This process acts at the expense of somatic growth or, as in the both studies, at the expense of reproduction. In fact growth rates estimated by means of growth rings were not significantly different between the two Tunisian populations (Sellem, personal observation). But the factors which act on somatic and gonadal growth are numerous and their interactions complex, that explains interannual variability and the contradictions of the literature on this topic. Only the increase of such studies in contrasting habitats or in experimental conditions will allow to better understand these processes. However, on an economic plan, the present study suggests all the interest to develop sea urchin fisheries in sheltered environment, protected from polluted waste waters and with, if possible, no limited fleshy macrophytes. 


\section{REFERENCES}

Bayed, A., Quiniou, F., Benrha, A. \& Guillou, M., 2005. The Paracentrotus lividus populations from the northern Moroccan Atlantic coast : growth, reproduction and health condition. Journal of Marine Biological Association of the United Kingdom, 85, 999-1007.

Beddingfield, S. D. \& McClintock, J.B., 1998. Differential survivorship, reproduction, growth and nutrient allocation in the regular echinoid Lytechinus variegates (Lamarck) fed natural diets. Journal of Experimental Marine Biology and Ecology, 226, 195-215.

Boudouresque, C.F. \& Verlaque, M., 2001. Ecology of Paracentrotus lividus. In : Edible Sea Urchins : Biology and Ecology. Developments in Aquaculture and Fisheries Science (ed. J.M. Lawrence), pp. 177-216. Elsevier Science Publishers B.V., Amsterdam.

Ben Charrada, R., 1997. Etude hydrodynamique et écologique du complexe Petit Golfe-Lac de Tunis. Contribution à la modélisation de l'écosystème pélagique des eaux côtières - Petit Golfe de Tunis. Thèse de Doctorat, Université des Sciences, des Techniques et de Médecine de Tunis, Tunisie.

Brewin, P.E., Lamare, M.D., Keogh, J.A. \& Mladenov, P.V., 2000. Reproductive variability over a four-year period in the sea urchin Evechinus chloroticus (Echinoidea: Echinodermata) from differing habitats in New Zealand. Marine Biology, 137, 543-557.

Byrne, M., 1990. Annual reproductive cycles of the commercial sea urchin Paracentrotus lividus from an exposed intertidal and sheltered subtidal habitat on the west coast of Ireland. Marine Biology, 104, 275-289. 
Crapp, G. B., \& Willis, M.E., 1975. Age determination in the sea urchin Paracentrotus lividus (Lamarck), with notes on the reproductive cycle. Journal of Experimental Marine Biology and Ecology, 20, 157-178.

Ebert, T.A., 1968. Growth rates of the sea urchin Strongylocentrotus purpuratus related to food availability and spine abrasion. Ecology, 49, 1075-1091.

Fanelli, G., Piraino, S., Belmonte, G., Geraci, S. \& Boero, F., 1994. Human predation along Apulian rocky coast (SE Italy): desertification caused by Lithophaga lithophaga (Mollusca) fisheries. Marine Ecology Progress Series, 110, 1-8.

Fenaux, L., 1968. Maturation des gonades et cycle saisonnier des larves chez Arbacia lixula, Paracentrotus lividus et Psammechinus microtuberculatus (Echinides) à Villefranche surMer. Vie et Milieu, 19, 1-52.

Fenaux, L. \& Pedrotti, M.L., 1988. Métamorphose des larves d'échinides en pleine eau. Pubblicazioni della Stazione Zoologica di Napoli : Marine Ecology, 9, 93-107.

Fernandez, C., Boudouresque, C.F., 1997. Phenotypic plasticity of Paracentrotus lividus (Echinodermata: Echinoidea) in a lagoonal environment. Marine Ecology Progress Series 152, 145-154.

Gago, J., Range, P. \& Luis, O., 2001. Growth, reproductive biology and habitat selection of the sea urchin Paracentrotus lividus in the coastal waters of Cascais, Portugal. In Echinoderm Research (ed. J.P. Féral \& B. David), pp. 269-276. A.A. Balkema. 
Gonor, J.J., Reproductive cycles in Oregon populations of the echinoid, Strongylocentrotus purpuratus (Stimpson). I. Annual gonad growth and ovarian gametogenic cycles. Journal of Experimental Marine Biology and Ecology, 12, 45-64.

Guettaf, M., San Martin, G.A. \& Francour, P., 2000. Interpopulation variability of the reproductive cycle of Paracentrotus lividus (Echinodermata: Echinoidea) in the south-western Mediterranean. Journal of the Marine Biological Association of the United Kingdom, 80, 899907.

Guillou, M. \& Lumingas, L.J.L., 1999. Variation in the reproductive strategy of the sea urchin Sphaerechinus granularis (Echinodermata : Echinoidea) related to food availability. Journal of the Marine Biological Association of the United Kingdom, 79, 131-136.

Guillou, M. \& Michel, C., 1994. The influence of environmental factors on the growth of Sphaerechinus granularis (Lamarck) (Echinodermata : Echinoidea). Journal of Experimental Marine Biology and Ecology, 178, 97-111.

Gras, G., 1987. Evolution des stocks de l'oursin comestible Paracentrotus lividus dans le quartier maritime de Marseille (France) soumis à une pêche intensive, entre les campagnes 1984-1985 et 1986-1987. In Colloque international sur Paracentrotus lividus et les oursins comestibles (ed. C.F. Boudouresque), pp. 363-370. GIS Posidonie, Marseille, France.

Himmelman, J.H., 1986. Population biology of green sea urchins on rocky barrens. Marine Ecology Progress Series, 33, 295-306. 
Keesing, J.K. \& Hall, K.C., 1998. Review of harvests and status of world sea urchin fisheries points to opportunities for aquaculture. Journal of shellfish research, 17, 1597-1604.

King, C.K., Hoegh-Guldberg, O. \& Byrne, M., 1994. Reproduction cycle of Centrostephanus rodgersii (Echinoidea), with recommendations for the establishment of a sea urchin fishery in New South Wales. Marine Biology, 120, 95-106.

Lawrence, J.M. \& Lane, J.M., 1982. The utilisation of nutrients by post-metamorphic echinoderms. In Echinoderm Nutrition (ed. M. Jangoux \& J.M. Lawrence), pp. 331-372. A.A. Balkema, Rotterdam.

Le Direac'h J.P., Boudouresque, C.F, Antolic, B., Kocastas, A., Panayotidis, P., Panucci, A., Semroud, R., Span, A., Zaouali, J. \& Zavodnik, D., 1987. Rapport sur l'exploitation des oursins en Méditerranée. In Colloque international sur Paracentrotus lividus et les oursins comestibles (ed. C.F. Boudouresque), pp. 329-334. GIS Posidonie, Marseille, France.

Lozano, J., Galera, J., L?pez, S., Turon, X., Palanc 2, C. \& Morera, G., 1995. Biological cycles and recruitment of Paracentrotus lividus (Echinodermata-Echinoidea) in two contrasting habitats. Marine Ecology Progress Series, 122, 179-191.

Martoja, R. \& Martoja, M., 1967. Initiation aux techniques de l'histologie animale. Paris: Masson. 
Meidel, S.K. \& Scheibling, R.E. 1998. Annual reproductive cycle of the green sea urchin, Strongylocentrotus droebachiensis, in differing habitats in Nova Scotia, Canada. Marine Biology, 131, 461-478.

Moylan, E.M., Sides, E.M. \& Byrne, M., 1998. The fishery and cultivation of Paracentrotus lividus in Ireland. In Echinoderms: San Francisco (ed. R. Mooi \& M. Telford), p761. Rotterdam, A.A. Balkema.

Régis, M.B., 1979. Analyses des fluctuations des indices physiologiques chez deux échinoïdes Paracentrotus lividus (Lmk.) et Arbacia lixula (L.) du golfe de Marseille. Théthys, 9, 167-181.

Régis, M.B., 1980. Etude des possibilités d'élevage des oursins réguliers en fonction de la valeur de certains indices physiologiques. Oceanologica Acta, 3, 7-15.

Sánchez-Espana, A.I., Mart?nez-Pita, I. \& Garc 3, F.J., 2004. Gonadal growth and reproduction in the commercial sea urchin Paracentrotus lividus (Lamarck, 1816) (Echinodermata : Echinoidea) southern Spain. Hydrobiologia, 519, 61-72.

Sellem, F., Langar, H. \& El Abed, A., 2001. Ecobiology and sustainable management of sea urchin in the southeast of the gulf of Tunis. In Proceedings of the Fifth International Conference on the Mediterraean Coastal Environment, MEDCOAST 01, Hammamet, Tunisia, 23-27 octobre 2001 (ed. E. Ozhan), vol.2 , pp. 833- 837. 
Semroud, R. \& Kada, H., 1987. Contribution à l'étude de l'oursin Paracentrotus lividus (Lamarck) dans la région d'Alger (Algérie) : indice de réplétion et indice gonadique. In Colloque international sur Paracentrotus lividus et les oursins comestibles, (ed.C.F. Boudouresque), pp. 117-124. GIS Posidonie, Marseille, France.

Southward, A. J. \& Southward, E., 1975. The endangered urchins. New Scientist, 66, 70-72.

Spirlet, C., Grosjean, P. \& Jangoux, M., 1998. Reproductive cycle of the echinoid Paracentrotus lividus: analysis by means of the maturity index. Invertebrate Reproduction and Development, 34, 69- 81.

Verlaque, M. \& Nédélec, H., 1983. Biologie de Paracentrotus lividus (Lam.) sur substrat rocheux en Corse (Méditerranée, France) : alimentation des adultes. Vie et Milieu, 33, 191201. 
Legends of the figures
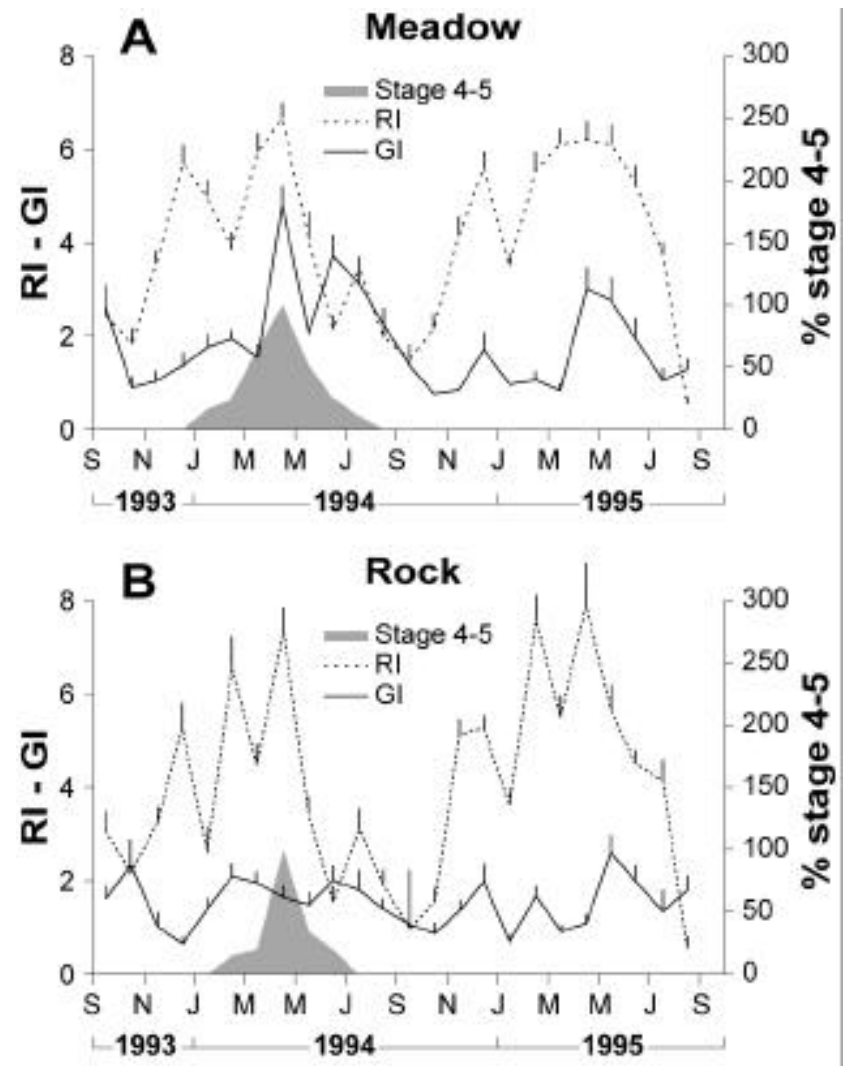

Figure 1. Sum of the relative frequencies of the gonadal stages 4 (mature stage) and 5 (partly spawned stage) from September 1993 to August 1994, and changes in the gonad index (GI) and the repletion index (RI) from September 1993 to August 1995 in the sheltered site "Meadow" (A) and the exposed site "Rock" (B). Bars are standard deviation. 


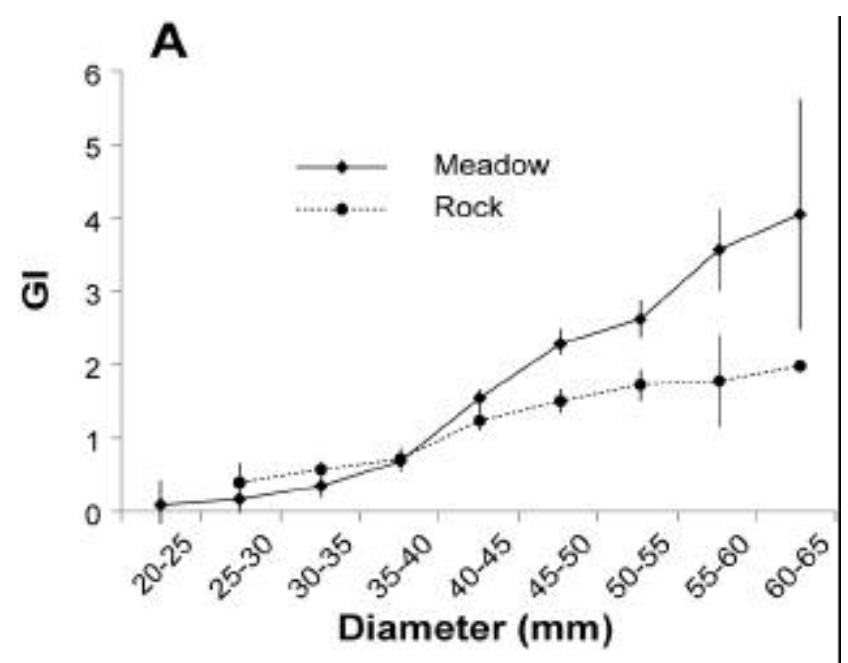

B

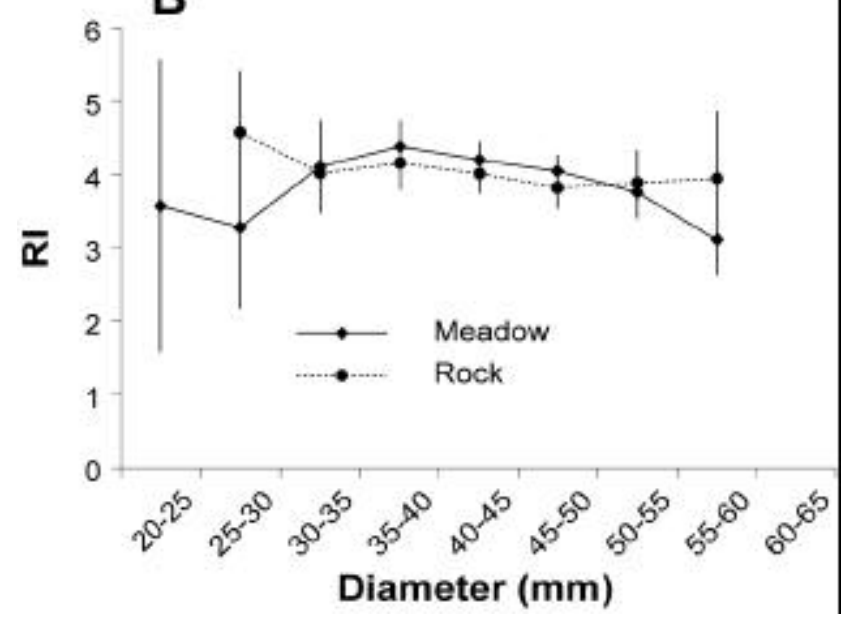

Figure 2. Gonad index, GI (A) and repletion index, RI (B) as a function of size (diameter sizeclasses in mm) from September 2003 to August 2004 (all data pooled) in the sheltered site "Meadow" and exposed site "Rock". Bars are confidence intervals, a =0.05. 